\title{
A DONOR-CONCEIVED CHILD'S RIGHT TO KNOW ITS GENETIC ORIGIN: A SOUTH AFRICAN PERSPECTIVE
}

\author{
Themba Skosana* \\ $L L B$ \\ Lecturer, College of Law \\ University of South Africa (UNISA)
}

\section{SUMMARY}

This paper addresses the need for donor-conceived children to know their genetic parents. The author focuses on the legal consequences of not knowing a genetic parent, as a basis to advocate for the recognition and protection of a donorconceived child's right to know its genetic parent. Further an analogy is drawn between donor-conceived and adopted children to advance the argument. The conclusion is that there is a need for legal reform, with regard to anonymous gamete donation in South African law.

\section{$1 \quad$ INTRODUCTION}

Most couples (heterosexual and same-sex) and single adults desire children of their own. It can be devastating for a person to discover that he or she suffers from permanent infertility. Developments in the medical field now offer alternatives in the form of assisted-reproduction techniques (artificial fertilization). This is a welcome development for an aspiring parent or aspiring parents. Often, medical or technological advancements create new legal minefields which require the law to develop at the same level and pace as the medical and/or technological advancements.

One such legal minefield may arise when a donor-conceived child enquires about his or her true identity. It is trite that human beings have an innate desire to know their true identity or their origin. There are categories of children who are vulnerable for not knowing their genetic parent. They include: children conceived by the use of donated gametes; children who have no record of their parents (often those of the father) on their birth certificate; and adopted children. The focus of this article is limited to children, having been conceived y the use of donated gametes.

The donor-conceived child's right to know his or her biological parent remains a contentious issue. It was extensively discussed in the South African Law Commission's Discussion Paper on the Review of the Child 
Care $A c t,{ }^{1}$ and thus it is not entirely new. ${ }^{2}$ This article aims to determine whether a donor-conceived child's right to know his or her biological origin is worthy of legal protection, both where the identity of the "gamete donor" is known, as well as where the identity of the gamete donor is unknown to the parents. The investigation focuses on the current position in South African law.

This topic is broad-based, as it may cover aspects of medical law, ethics, and psychology. However, the discussion in this article is limited to the following areas: child law; family law; and certain aspects of human rights. The discussion is restricted to the South African position. The following structure is adopted: the article starts by highlighting some of the important concepts regarding artificial fertilization and its regulation. Then it deals with some of the consequences of not knowing one's genetic parent. This discussion is followed by an investigation of the right to know genetic parents of donor-conceived children, with specific focus on existing legislation. The position of adopted children is compared to the position of donor-conceived children. The article ends with some recommendations on the electronic central data bank and an avenue to remedy the unconstitutionality of section $41(2)$ of the Children's Act, ${ }^{4}$ read together with regulation 19 of Regulations Relating to Artificial Fertilisation of Persons. ${ }^{5}$

\section{ARTIFICIAL FERTILIZATION}

\section{Legal framework and definition of important concepts}

Previously, artificial fertilization was regulated in terms of the Human Tissue Act, ${ }^{6}$ together with the Children's Status Act. ${ }^{7}$ These Acts have since been

* The author is indebted to Prof Jacqueline Heaton and Prof Hanneretha Kruger for their comments during the drafting stages of this article.

1 South African Law Commission Discussion Paper 103 Review of the Child Care Act 152154. The Commission points out that: "several writers, both in South Africa and abroad have argued that these kind of restrictions contravene the fundamental right of children born as a result of artificial insemination procedures to know about their biological origins and thus to have access to biological information concerning their genetic parents. In view of these arguments and of the fact that adopted children in South Africa are entitled to have access to their adoption records once they reach the age of 21 , the 'confidentiality provisions' of the Human Tissue Act and regulations may need amendment".

2 Lupton "Artificial Insemination in South Africa in the light of the Human Tissue Act 65 of 1983" 1985 THRHR 210-218; Lupton "The Right to be Born: Surrogacy and the Legal Control of Human Fertility" 1988 De Jure 39-41.

3 "Gamete donor" means a living person from whose body a gamete or gametes are removed or withdrawn, for the purpose of artificial fertilization (Regulations relating to the Artificial Fertilisation of Persons National Department of Health. Notice 175: Regulations Relating to the Artificial Fertilisation of Persons. Pretoria: GG 9699 of 2012-03-02) (hereinafter "GN 175 in GG 9699 of 2012-03-02") reg 1).

38 of 2005.

5 GN 175 in GG 9699 of 2012-03-02.

65 of 1983.

82 of 1987. Skelton "Surrogate Motherhood" in Davel and Skelton (eds) Commentary on the Children's Act (2012) 19-4 highlights that the Children's Status Act and the Human Tissue Act did not address the issue of surrogacy directly. 
repealed by the National Health $\mathrm{Act}^{8}$ and Children's $\mathrm{Act}^{9}{ }^{9}$ respectively. Currently, artificial fertilization is regulated in terms of the National Health Act $^{10}$ and the Children's Act. ${ }^{11}$ The National Health Act came into effect on 1 March 2012, while certain sections of the Children's Act came into effect on 1 July 2007 and the rest of the provisions on 1 April 2010.

Two forms of artificial fertilization are recognised in the Children's Act, and the National Health Act, that is: artificial insemination ${ }^{12}$ and surrogacy. ${ }^{13}$ Artificial insemination refers to the placing of male gametes (sperm) into the female reproductive tract by means other than sexual intercourse. ${ }^{14}$ Surrogacy refers to the placing of the product of a union of male or female gametes which have been brought together outside the human body, in a womb of a female person. ${ }^{15}$ There are two types of surrogacy: full (or gestational) and partial surrogacy. In terms of full surrogacy the child is conceived using the ovum of the commissioning mother and the sperm of the commissioning father. ${ }^{16}$ Partial surrogacy involves fertilizing the surrogate mother's ${ }^{17}$ own ovum using sperm from either the commissioning father or a donor. In the case of full surrogacy the surrogate mother has no genetic relationship with the child, while in the latter case the surrogate mother is also a genetic parent of the child, because her ovum has been used.

All the procedures regarding artificial fertilization are regulated by the National Health Act, ${ }^{18}$ and regulations issued under it (Regulations Relating to Artificial Fertilisation of Persons hereinafter "Regulations"). ${ }^{19}$ These regulations apply only to the withdrawal of gametes from, and for use in, living persons. ${ }^{20}$ The discussion of artificial fertilization in this paper includes both artificial insemination and surrogacy. Thus any reference to a donorconceived child in this paper includes children born either through artificial insemination or surrogacy.

S 93 of 61 of 2003.

S 313 of 38 of 2005, read together with item 5 in Sch 4.

61 of 2003.

38 of 2005.

12 Reg 1 of GN 175 in GG 9699 of 2012-03-02 states that these procedures may be performed either through in vitro fertilization (IVF) or intracytoplasmic sperm injection.

13 Ch 19 of 38 of 2005 permits and regulates surrogate-motherhood agreements and attributes legal consequences to the agreement if the agreement complies with the requirements set out in the Act; reg 1 of GN 175 in GG 9699 of 2012-03-02 states that these procedures may be performed either through gamete intra-fallopian tube transfer (GIFT) or embryo intra-fallopian transfer.

14 Ibid.

15 lbid.

16 S 1 of 38 of 2005: "Commissioning Parent" means a person who enters into a surrogatemotherhood agreement with a surrogate mother. See also Schäfer Child Law in South Africa (2011) 276; Louw "Surrogate Motherhood" in Davel and Skelton (eds) Commentary on the Children's Act (2012) 19-3.

17 S 1 of 38 of 2005: "Surrogate Mother" means an adult who enters into a surrogatemotherhood agreement with the commissioning parents.

18 Ss 55,56 and 60 of 61 of 2003.

19 GN 175 in GG 9699 of 2012-03-02.

20 Reg 1 of GN 175 in GG 9699 of 2012-03-02. 
The Children's Act does not provide a definition of the term "genetic parent". ${ }^{21}$ Nor does the Children's Act provide a definition of a "parent". Instead it merely excludes certain persons from being regarded as a parent. For example, any person who is biologically related to a child by reason only of being a gamete donor for purposes of artificial fertilization is excluded as a parent. ${ }^{22}$ Therefore for purpose of this article the term "gamete donor" is mostly used instead of genetic parent. ${ }^{23}$

\section{Regulation of gamete donation with regard to the identity of the gamete donor}

The Children's Act makes provision for the donor-conceived child to access biographical and medical information concerning genetic parents. Section 41 provides that:

"(1) A child born as a result of artificial fertilisation or surrogacy or the guardian of such a child is entitled to have access to -

(a) any medical information concerning that child's genetic parents; and

(b) any other information concerning that child's genetic parents but not before the child reaches the age of 18 years."

The Children's Act further guarantees the identity protection of the gamete donors, as section 41 further provides that:

"(2) The information disclosed in subsection (1) may not reveal the identity of the person whose gamete was or gametes were used for such artificial fertilisation or the identity of the surrogate mother."

Furthermore, regulation 19 under the regulations provides that no person shall disclose the identity of any person who donated a gamete or received a gamete, or any matter related to the artificial fertilization of such gametes, or reproduction resulting from such artificial fertilization except where a law provides otherwise or a court so orders. ${ }^{24}$

There is a notable conflict between the regulations and the Children's Act. Section 41(2) of the Children's Act imposes an absolute restriction on the disclosure of the identity of the gamete donor, whilst the regulations provide for an exception on the restriction. Since the regulations constitute subordinate legislation, the rule applies that, where subordinate legislation is in conflict with primary legislation, the primary legislation should prevail to resolve the conflict. ${ }^{25}$

With regard to the birth registration of a donor-conceived child, regulation 16(1) and (2) makes provision for the reporting of a birth as a result of artificial fertilization and the type of information to be recorded. It provides:

21 Skelton "Parental Responsibilities and Rights" in Davel and Skelton (eds) Commentary on the Children's Act (2012) 3-50.

$22 S 1(1)$ of 38 of 2005 , for purposes of this article not all exclusions are discussed.

23 See fn 3 above.

24 GN 175 in GG 9699 of 2012-03-02.

25 Botha Statutory Interpretation: An Introduction for Students 5ed (2012) 28. 
“(a) All births delivered as result of artificial fertilisation shall be recorded by the person in charge of the facility where such delivery has taken place, into the central data bank within 3 months of such birth.

(b) The mother who gives birth shall ensure that the competent person who effected the artificial fertilization of or embryo transfer is informed of such birth and recording of the information referred to in subregulation (2), within 30 days of such birth."

Furthermore subregulation (2) provides that the information recorded in terms of subregulation (1) shall include, but is not limited to:

"(a) confirmation of birth;

(b) [t]he unique identification number referred to in regulation 11(a); and

(c) any genetic disorder or birth defect in the child."

From the above provisions it follows that gamete donation is done anonymously in South Africa and that the donor-conceived child may not have access to information which reveals the identity of the gamete donor, unless the parties voluntarily provide for such disclosure.

Regulation 5 provides that the Director-General shall establish an "electronic central data bank"26 into which all information regarding gamete and embryo donation is stored. The electronic central data bank has not yet been established. Moreover, regulation 6(c) requires that a competent person must immediately relay all the information relating to such gamete donor, the removal or withdrawal of a gamete or artificial fertilization, to the central data bank, contemplated in regulation 5. Regulation 8 requires that all the personal information regarding a gamete donor must be recorded in the gamete-donor file before any donation is made by a competent person. ${ }^{27}$ The fertility clinics keep their own records; thus currently information regarding artificial fertilization is self-regulatory within the fertility clinics.

The South African Register of Assisted Reproductive Techniques (SARA) which is a subcommittee constituted under the Southern African Society of Reproductive Medicine and Gynaecological Endoscopy (SASREG), ${ }^{28}$ together with the fertility clinics affiliated under SASREG currently keep records of gamete donation is South Africa. ${ }^{29}$ The submission of data to SARA by individual Assisted Reproductive Techniques centres is voluntary.

26 Reg 1 of GN 175 in GG 9699 of 2012-03-02: "Electronic Central Data Bank" means an electronic bank in which all information regarding artificial fertilization treatment outcome is stored and managed.

27 Reg 1 of GN 175 in GG 9699 of 2012-03-02 defines a "Competent Person" in relation to artificial fertilization as a person registered as such in terms of the Health Profession Act 56 of 1974; who is -

(a) A medical practitioner practising in gynaecology with training in reproductive medicine;

(b) a medical scientist; medical technologist; clinical technologist; with training in reproductive biology and related laboratory procedures.

28 SASREG is a society that represents gynaecologists with a special interest in gynaecological endoscopy and reproductive medicine (infertility, reproductive endocrinology, menopause and contraception); subspecialists in reproductive medicine; embryologists and scientists working in the field of reproductive medicine; fertility and theatre-nursing sisters; allied practitioners in the field of gynaecological endoscopy and reproductive medicine www.fertilitysa.org.za (accessed 2015-11-03).

29 SARA report 2009, SARA report 2010, SARA report 2011, SARA report 2013 www.fertilitysa.org.za (accessed 2015-11-03). 
The centres which participate submit annual data to the SARA Administrator in a format provided by SARA, and within stipulated timelines and sign a Memorandum of Understanding. The records kept by SARA and fertility clinics are not regulated under the regulations.

\section{THE RIGHTS OF DONOR-CONCEIVED CHILDREN}

\section{Introduction}

This section investigates the legal right of the child to know the identity of the gamete donor. As indicated above, the concept of the right to know one's biological origin is not a completely new concept in South African law in relation to children, as it was canvassed in the Discussion Paper on the Review of the Child Care Act. ${ }^{30}$ However, in South African law there is no judicial statement on whether a donor-conceived child has a right to know information which reveals the identity of the gamete donor; nor, it seems, has a child in South Africa ever sought to assert the right to know the identity of the gamete donor. ${ }^{31}$

It is important to define the meaning of the concept of the right to know one's genetic origin. Mosikatsana ${ }^{32}$ notes that the right to an identity has important psychological and emotional content because a name connects a child to his or her family. Cameron, Gruben and Kelly ${ }^{33}$ define "knowing one's genetic origin" variably to include a right to access health and psychosocial information, to know the identity of the gamete donor, or even to meet and form a relationship with the donor. Besson ${ }^{34}$ defines the right to know one's origins as the right to know one's parentage, ie, one's biological family and ascendance, and one's conditions of birth.

The issue of acquiring knowledge concerning a gamete donor has several implications. First, it relates to the secrecy issue which concerns the question whether a child should be informed that he or she was conceived by means of donor material. Secondly it relates to donor anonymity which concerns divulging the donor's identity to the donor-conceived child. With regard to the first issue, it is obvious that a child cannot ask information about his or her genetic parent as long as he or she does not have any idea that the social parent(s) is/are not his or her genetic parent(s). The obvious situation which may prompt a child to have questions regarding his or her genetic parent is where, for example, the parents are same-sex partners. Thus same-sex partners may inevitably have to answer questions regarding

\footnotetext{
See fn 2 above.

$A B$ \& Surrogacy Advisory Group $v$ The Minister of Social Development \& Centre for Child Law (as Amicus Curiae) (40658/13) [2015] ZAGPPHC 580 par 84.

32 Mosikatsana "Children's Rights and Family Autonomy in the South African Context: A Comment on Children's Rights under the Final Constitution" 1998 Michigan Journal of Race \& Law 370. See also Besson "Enforcing the Child's Right to Know her Origins: Contrasting Approaches under the Convention on the Rights of the Child and the European Convention on Human Rights" 2007 International Journal of Law, Policy and of Family 138. Cameron, Gruben and Kelly "De-anonymising Sperm Donors in Canada: Some Doubts and
Directions" 2010 Canadian Journal of Family Law 109.

34 Besson 2007 International Journal of Law, Policy and of Family 140.
} 
the absence of a mother or father, and the inquiry may eventually lead to questions regarding the identity of the child's genetic parent.

The decision to inform the child of his or her biological origin lies with the persons to whom parental responsibilities and rights have been assigned; this is so because the Children's Act does not differentiate between a social or legal, and biological or genetic parent; or provides a definition of a parent. ${ }^{35}$ The discussion below investigates whether the rights of donorconceived children are recognized and protected under the United Nations Convention of the Rights of the Child of 1989 (CRC).

\section{United Nations Convention on the Rights of the Child}

The CRC was adopted by the United Nations General Assembly on 20 November 1989. South Africa ratified the CRC on 16 July 1995. The CRC has been domesticated through the Children's Act and as such forms part of domestic law. ${ }^{36}$ One of the objects of the Children's Act, is to "give effect to the Republic's obligations concerning the well-being of children in terms of international instruments binding on the Republic". ${ }^{37}$ Along the same vein, article 2 of the CRC provides that:

"States Parties shall respect and ensure the rights set forth in the present Convention to each child within their jurisdiction without discrimination of any kind, irrespective of the child's or his or her parent's or legal guardian's race, colour, sex, language, religion, political, or opinion, national, ethnic or social, property, disability, birth or other status."

Of importance with regard to the CRC in the context of the right to know is article 7 which provides that:

“(1) The child shall be registered immediately after birth and shall have the right from birth to a name, the right to acquire a nationality and as far as possible, the right to know and be cared for by his or her parents.

(2) States Parties shall ensure the implementation of these rights in accordance with their national law and their obligations under the relevant international instruments in this field, in particular where the child would otherwise be stateless."

Article 7(1) explicitly recognizes the "right to know". Similar to the Children's Act, the CRC does not define a "parent". A number of scholars have interpreted "parent" in article 7(1) to include not only social or legal, but also a biological or genetic parent. ${ }^{38}$

35 See fn 21 above. See also s 1(1) of 38 of 2005, which expressly excludes three categories of persons from legally qualifying as a child's "parent". They include: The biological father of a child who was conceived through rape of the child's mother or incest with her; any person who is biologically related to a child by reason only of being a gamete donor of artificial fertilization; a parent whose parental responsibilities and rights in respect of the child have been terminated.

36 See also C v Department of Health and Social Development, Gauteng 2012 (2) SA 208 (CC) par 25.

37 S 2(c) of 38 of 2005.

38 Freeman "The New Birth Right?: Identity and the Child of the Reproductive Revolution" 1996 International Journal of Children's Rights 273-297; Frith "Gamete Donation and 


\section{JUSTIFICATION FOR THE RECOGNITION OF THE DONOR-CONCEIVED CHILD TO KNOW A GENETIC PARENT}

\section{Introduction}

The previous section highlights that the right to know a genetic parent is not recognized or protected in South African law. This section investigates the justification for recognition of the right to know a genetic parent. The argument looks at consequences of not knowing a genetic parent.

\section{Accidental incest and violation of the prohibition on marriage within the prohibited degrees of relationship}

Some of the legal consequences regarding the donor-conceived child not knowing the identity of the gamete donor may include: a prohibited marriage between the donor and his or her offspring or between the donor's offspring (not restricted only to these two) and a possible incestuous sexual relationship. In South African law a marriage or sexual intercourse between persons who are related within the prohibited degrees of relationship is prohibited. ${ }^{39}$ These persons could either be related by blood (consanguinity) or related by marriage (affinity). In a case of accidental incest section 12 of the Criminal Law (Sexual Offences and Related Matters) Amendment Act ${ }^{40}$ provides that incest is a criminal offence.

The current legal position allows gamete donors the right to remain anonymous. This raises the question of whether section $41(2)$ of the Children's Act abolished the rule of marriage law, which prohibits marriage between persons who are related by blood or affinity in respect of donorconceived persons and incest. ${ }^{41}$ As it is improbable that the legislature would have intended to introduce such a drastic departure from legislation and common law by way of enacting section $41(2)$, it appears that this was simply an oversight on the side of the legislator. In this regard the analogy of

Anonymity the Ethical and Legal Debate" 2001 Human Reproduction 820; Murray and Golombok "To Tell or Not to Tell: The Decision-making Process of Egg-donation" 2003 Human Fertility 90; Mentor "Gamete Donation, Identity, and the Offspring's Right to Know" 2007 American Medical Association Journal of Ethics 645; Blauwhoff "Tracing Down the Historical Development of Legal Concept of the Right to know One's Origins. Has 'to know or not to know' ever been the legal question?" 2008 Utrecht LR 99.

39 Dhai "Limiting Donor Conceptions to Six: Time for Change" 2014 South African Journal of Bioethics and Law 2. See also Schäfer Child Law in South Africa 281, who notes that the Children's Act is silent on whether the relation between the child and his or her surrogate mother or her husband's or partner's relatives falls within the prohibited degrees of affinity and consanguinity within which sexual intercourse and marriage are prohibited.

4034 of 2007, which provides that persons who may not lawfully marry each other on account of consanguinity, affinity or an adoptive relationship, and who unlawfully and intentionally engage in an act of sexual penetration with each other, are, despite their mutual consent to engage in such act, guilty of the offence of incest.

41 Schäfer Child Law in South Africa 281. 
adoption is apt. The following section draws an analogy with the position of adopted children in the Children's Act.

\section{AN ANALOGY WITH ADOPTED CHILDREN}

This section draws an analogy with adopted children, with specific focus on the right to know a genetic parent and an incestuous relationship. The developments in the field of adoption, where there was a move away from anonymous or closed adoption towards openness with regard to adoption, justify drawing this analogy. Openness in adoption was realized under the Child Care Act, ${ }^{42}$ and now also features in the Children's Act. ${ }^{43}$ This fact strongly inspires an argument against gamete-donor anonymity. Louw sums up "openness" in adoption as follows:

"the disclosure or identifying particulars at the time of the adoption; the extent to which the biological parents, adoptive parents and/or adopted children are allowed access to adoption records; post-adoption contact, which may be either of an indirect nature, for example agreeing to exchange letters, photographs through an agency after the adoption, or direct, such as meetings in person between the adopted child and his or her biological parents or even grandparents or other persons with whom the child has built up a relationship before the adoption."

When a children's court grants an adoption order in respect of a child whose birth has been registered in the Republic, the adoptive parent of the child must apply in terms of the applicable law (the Births and Deaths Registration Act 51 of 1992) to the Director-General: Home Affairs to record the adoption and any change of surname of the child in the births register. ${ }^{45}$

Furthermore section 248(1)(a) of the Children's Act provides that the information in the adoption register about an adopted child may not be disclosed to any person except to an adopted child, after the child has reached the age of 18 years. ${ }^{46}$ At such stage the adopted person is no longer a minor; thus the issue of access to information regarding the identity of the biological parent can no longer be dealt with under children's rights or the Children's Act. The same provision creates an exception in section 248(1)(e), which provides that the information contained in the adoption register may be accessed by an order of Court, if the Court finds that such disclosure is in the best interests of the adopted child. ${ }^{47}$ This latter provision

42 S 60(1)(h) of Child Care Act 74 of 1983 provided that "[t]he Minister may make regulations as to the method of registration of order of adoption, including the appointment of a registrar of adoptions and his powers and duties and the particulars regarding any adoption that may be disclose ..." See also Louw "Open Adoption: Panacea or Pandora's Box" 2003 De Jure 254-264.

$43 \mathrm{~S} 248(1)$ of 38 of 2005

44 Louw 2003 De Jure 256-257.

45 S 245(1) of 38 of 2005. The Department of Home Affairs still refers to $s 25$ of the Child Care Act; this is possibly an administrative error, as the latter Act has been repealed. See also http://www.dha.gov.za/index.php/adoption1 (accessed 2015-11-18). The Regulations relating to Children's Courts and International Child Abduction (2010) (R 250 in GG 33067 of 31-03-2010) deal with the manner of recording information in the adoptions register. See also s 247 of 38 of 2005 .

4638 of 2005.

47 Ibid. 
implies that an adopted child may access the adoption register before the adopted child attains majority, if such disclosure is in the best interests of the adopted child.

Secondly on the issue of an incestuous relationship section 242(2)(c) of the Children's Act provides that an adoption order does not permit any marriage or sexual intercourse between the child and any other person, which would have been prohibited had the child not been adopted. ${ }^{48}$ It is thus clear that an adopted child's chances of committing accidental incest are minimal. The fact that an adoption order is registered with the Department of Home Affairs, further limits chances that an adopted child will marry anyone whom he or she would not have been permitted to marry.

\section{EQUALITY BETWEEN DONOR-CONCEIVED AND ADOPTED CHILDREN}

The differentiation between adopted and donor-conceived children as regards access to information that identifies their biological parents may be challenged on constitutional grounds in terms of the equality clause in the Constitution. ${ }^{49}$

The Constitutional Court in Harksen $v$ Lane $N \mathrm{O}^{50}$ tabulated the stages of an inquiry into a violation of the equality clause as follows:

(a) Does the provision differentiate between people or categories of people? If so, does the differentiation bear a rational connection to a legitimate government purpose? If it does not then there is a violation of section 9(1) of the Constitution. Even if it does bear a rational connection, it might nevertheless amount to discrimination.

(b) Does the differentiation amount to unfair discrimination? This requires a two-stage analysis:

(i) Firstly, does the differentiation amount to "discrimination"? If it is on a specified ground, then discrimination will have been established. If it is not on a specified ground, then whether or not there is discrimination, will depend upon whether, objectively, the ground is based on attributes and characteristics which have the potential to impair the fundamental human dignity of persons as human beings or to affect them adversely in a comparably serious manner.

(ii) If the differentiation amounts to "discrimination", does it amount to "unfair discrimination"? If it has been found to have been on a specified ground, then unfairness will be presumed. If on an unspecified ground, unfairness will have to be established by the complainant. The test of unfairness focuses primarily on the impact of the discrimination on the complainant and others in his or her situation.

(a) If, at the end of this stage of the enquiry, the differentiation is found not to be unfair, then there will be no violation of section $9(2)$.

Section 9(1) provides that everyone (in this instance, all children) is equal before the law and has the right to equal protection and benefit of the law, ${ }^{51}$ while section 9(3) provides that:

\footnotetext{
38 of 2005.

$49 \mathrm{~S} 9$ of the Constitution.

50 Harksen v Lane NO 1998 (1) SA 300 (CC) par 53.
} 
"The State may not unfairly discriminate directly or indirectly against anyone on one or more grounds, including race, gender, sex, pregnancy, marital status, ethnic or social origin, colour, sexual orientation, age, disability, religion, conscience, belief, culture language and birth."

Adopted children and donor-conceived children arguably share similar attributes and should therefore be treated alike. ${ }^{52}$ The likeness may be based on the fact that both adoption and conceiving a child via a donated gamete, creates a parent-child relationship, based on a social rather than a genetic link, or a mixture of one genetic parent and one social parent. ${ }^{53}$ Both adoption and artificial fertilization lead to parenthood. Blyth et $a^{54}$ state that adoption is a means of ensuring parental care for children, whereas the objective of donor-assisted conception is to provide children for adults.

In Peterson $v$ Maintenance Officer, ${ }^{55}$ the Cape Provincial Division of the High Court (now the Western Cape High Court, Cape Town) dealt with the constitutionality of a common-law rule, established in Motan $v$ Joosub. ${ }^{56}$ The rule provided that maternal and paternal grandparents have a duty to support their legitimate grandchild (now referred to as a "grandchild born of married parents"), but in the case of an illegitimate grandchild (now referred to as a "grandchild born of unmarried parents"), only the maternal grandparents are so burdened. This inequality resulted in unfair discrimination between legitimate (now referred as "children born of married parents") and illegitimate children ("children born of unmarried parents") on the ground of birth. As a result, the constitutionality of this rule was challenged on the grounds of the equality clause. To remedy this unconstitutionality, Fourie $\mathrm{J},{ }^{57}$ extended the legal duty to support also to paternal grandparents of illegitimate children. Although the matter does not deal with donor-conceived children, the Court had to deal with unfair discrimination on the grounds of birth, which is the same listed ground in this discussion.

Section 41(2) of the Children's Act read together with regulation 19 arguably unfairly discriminates against donor-conceived children, on a listed ground of birth. ${ }^{58}$ In terms of section $9(5)$ of the Constitution, where discrimination is based on one of the grounds listed in section 9(3) (in this case, birth) discrimination is presumed to be unfair until the contrary is proved. ${ }^{59}$ This entails a determination whether the infringement in this instance can be justifiable under the limitation clause. Thus an infringement justified in accordance with the criteria in section 36 of the Constitution is

51 S 9(1) of the Constitution.

52 Currie and De Waal Bill of Rights 6ed (2013) 213.

53 Blyth, Crawshaw, Haase and Speirs "The Implications of Adoption for Donor Offspring following Donor-assisted Conception" 2001 Child and Family Social Work 297-298.

Blyth, Crawshaw, Haase and Speirs 2001 Child and Family Social Work 298.

55 [2004] 1 All SA 117 (C) (also reported as Peterson v Maintenance Officer, Simon's Town Maintenance Court 2004 (2) SA 56 (C)). See also Fraser v Children's Court, Pretoria North 1997 (2) SA 261 (CC) par 20 (also reported as Fraser v Children's Court, Pretoria North 1997 (2) BCLR 153 (CC)).

$56 \quad 1930$ AD 61 par 22.

572004 (2) SA 56 (C) par 27.

$58 S 9(3)$ of the Constitution.

59 Currie and De Waal Bill of Rights 227. 
constitutionally valid. In order to address the section 36 criteria a two-stage analysis is applied. In this case a right in the Bill of Rights has been infringed, namely the right to equality. Therefore the enquiry shifts to whether the infringement can be justified as a permissible limitation of this right (this frequently involves a more factual enquiry than the question of interpretation).

Section 36(1) of the Constitution provides that:

"The rights in the Bill of Rights may be limited only in terms of law of general application to the extent that the limitation is reasonable and justifiable in an open and democratic society based on human dignity, equality and freedom, taking into account all relevant factors, including:

(a) The nature of the right;

(b) the importance of the purpose of the limitation;

(c) the nature and extent of the limitation;

(d) the relation between the limitation and its purpose; and

(e) less restrictive means to achieve the purpose."

The first stage tests whether the law or conduct has a rational basis; that is a rational connection between the differentiation in question and a legitimate Government purpose that is designated to further or achieve. In this instance section 41(2) of the Children's Act, read together with regulation 19, does not state what the provision seeks to achieve. Removing donor anonymity may impact negatively on gamete donors in the following respects: it could infringe on the privacy interests of the donor; ${ }^{60}$ the donor may suffer disruption of his marriage and family life; absence of donor anonymity may lead to reluctance to donate gametes, and consequently to a shortage of gametes for donation. It is arguable that the said provision seeks to protect the gamete donor's identity for these reasons. Mentor ${ }^{61}$ points out that if non-anonymous donation is the morally right way of organizing gamete donation, then the low donor number is the price that has to be paid for a morally sound system.

On the other hand section 41(2) of the Children's Act, read together with regulation 19, applies specifically to donor-conceived children, and it does not apply equally to all children (namely all donor-conceived, together with adopted children), and thus its application is arbitrary in comparison with adopted children. This then paves the way to test section 41(2) of the Children's Act, read together with regulation 19, against the listed factors which apply to section 36 of the Constitution. This would test whether the limitation is reasonable and justifiable.

The first factor is the nature of the right: section 41(2) of the Children's Act, read together with regulation 19 , does not allow a donor-conceived child to know the identity of the gamete donor. As indicated above the consequence of donor-conceived children not knowing the identity of the gamete donor may lead to a possible incestuous sexual relationship and a prohibited marriage between the donor and his or her offspring or between the donor's offspring. Therefore the object of section 41(2) of the Children's Act, read together with regulation 19 , is not a persuasive justifiable limitation

60 S14 of the Constitution.

61 Mentor 2007 American Medical Association Journal of Ethics 646. 
to a donor-conceived child's right to equality and to the best-interests-of-achild standard.

Secondly, the importance of the purpose of the limitation: In order to determine whether the purpose of the impugned provision is a legitimate one, the reasons for anonymous gamete donation in these provisions should be spelt out (as stated above, the provision is silent as to why the identity of the gamete donor should not be revealed). This will enable a determination on the weight of any possible competing rights of the gamete donor and the donor-conceived child. In this instance the limitation indirectly nullifies the possibility of a crime of incest, created in terms in terms of statute. ${ }^{62}$ It is important for South Africa to comply with the international obligation set out in the article 7(1) of the CRC which makes provision for a child's right to know their parents. Furthermore, the limitation could realistically encroach on a common-law rule of marriage, which prohibits marriage between persons who are related by blood or affinity. ${ }^{63}$ It also does not take into account the best-interests-of-a-child standard. ${ }^{6}$

Thirdly, the nature and extent of the limitation: It has to be determined whether the violation constitutes a serious violation of the child's right. In this instance the potentially serious consequences of a donor-conceived child not knowing their genetic parents are indicated above. Therefore to allow the limitation is arguably likely to do more damage than is reasonable to achieve the purpose in section 41(2) of the Children's Act, read together with regulation 19. A further South African empirical study may be required to determine whether donor-conceived children not knowing their genetic parents has any serious impact which may not be in their best interests.

Fourthly, the relation between the limitation and its purpose: Skweyiya $\mathrm{J}$ held that "in determining the appropriate relationship between the limitation and its important purpose, it is helpful to consider applicable international law". ${ }^{65}$ Article $7(1)$ of the CRC provides that a child has a right to know his or her parent. ${ }^{66}$ As mentioned, the reasons for anonymous gamete donation are not spelt out in the Children's Act and the regulations. Thus it is important for the Children's Act and the regulations to clearly spell out the purpose of anonymous gamete donation before it is determined whether anonymous gamete donation serves any justifiable limitation in terms of South African law.

Lastly, less restrictive means to achieve the purpose: It is indicated below in the recommendations, ${ }^{67}$ that revealing the information of the gamete donor to a donor-conceived child, when they reach 18 years, would be a less restrictive means to achieve the purpose.

\footnotetext{
See fn 36 above.

Heaton and Kruger South African Family Law 4ed (2015) 26-28. See also fn 39 above.

S 28(2) of the Constitution and $\mathrm{s} 7$ of the Children's Act. See also $S \vee M$ (Centre for Child Law as Amicus Curiae) 2007 (12) BCLR 1312 (CC).

65 C v Department of Health and Social Development, Gauteng 2012 (2) SA 208 (CC) par 32.

66 See paragraph 32 above.

67 See paragraph 7 below.
} 


\section{THE WAY FORWARD}

This article proposes a few recommendations on two issues: the electronic central data bank and how to possibly remedy the unconstitutionality of section 41(2) of the Children's Act, read together with regulation 19.

First, it is important for the Director-General to establish an electronic central data bank as recommended in regulation 5 . The electronic central data bank keeps all information regarding gamete and embryo donations. The establishment of the electronic central data bank is important to ensure compliance with the regulations: for instance it could assist to ensure restrictions of gamete-donation compliance; it will maintain consistency within the different fertility clinics, and assist offspring to discover whether a prohibited relationship exists between intended spouses. This could assist to avoid incidents of incestuous relationships. Whilst regulations mandate the Director-General of Health to establish an electronic central data bank, it is important that the electronic central data bank is housed under the Department of Home Affairs, similar to the adoption register.

Secondly, South Africa has to enact a provision that permits donorconceived children, over the age of majority (18 years) - should they so wish - to access information relating to the identity of the gamete donor. This will remedy the unconstitutionality in section 41(2) of the Children's Act, read together with regulation 19. The introduction of such a provision should not apply retroactively. ${ }^{68}$ Further, the provision should permit any citizen of marriageable age to approach the electronic central data bank (which should be established in terms of regulation 5) ${ }^{69}$ before he or she marries, in order to establish whether he or she was conceived as a result of artificial fertilization. If the answer is in the affirmative, the person should be informed whether his or her intended spouse is related to the gamete donor in any way. ${ }^{70}$

\section{CONCLUSION}

In South African law there is no provision for donor-conceived children to have a legal right to know the identity of their genetic parents. The article has highlighted pieces of legislation and areas of the law that justify the recognition of donor-conceived children's right to know, and the consequences of the non-recognition of such a right. Further the area of adoption is used as an analogy to advance the argument for recognition of this right for donor-conceived children. The current legal framework for anonymous gamete donation should be revisited, in order to address the following: the donor-conceived child's right to know the genetic parent upon reaching the age of 18 years, and the prohibition of incestuous relationships amongst related donor-conceived children and with the donor.

\footnotetext{
68 Pennings "How to Kill Gamete Donation: Retrospective Legislation and Donor Anonymity" 2012 Human Reproduction 2884.

69 Reg 5 GN 175 in GG 9699 of 2012-03-02.

70 Cameron, Gruben and Kelly 2010 Canadian Journal of Family Law 141.
} 